\title{
ON COAST LINE OSCILLATIONS DURING LAST DECADES. BORSHI BEACH CASE, ALBANIAN RIVIERA
}

\author{
Marku S. ${ }^{1}$ and Doda V. ${ }^{1}$ \\ Albanian Geological Survey, Rruga e Kavajës Nr.153,Tiranë,_Albania,marku_s@gsa.gov.al
}

\begin{abstract}
The oscillations of coast line in Albania, and simultaneously the Quaternary deposits in Albania were little studied until the decade of $90^{\text {th }}$ of $20^{\text {th }}$ century. Up to now, the studies consider those deposits as fluvial sediment; meanwhile, the coast line was categorized as of erosional and accumulative type. In those studies, the role of sea waves and euastatic change of sea level in the process of sediment supply in coastline is neglected. Transgression and regression was interpreted according to Theory of Geosynclinals, as tectonic subsidence or uplift of continental area. From observations in Borshi beach, during August 2013 and September 2015, result that the sediment in this area originate mainly from the erosion of coast line rocks, and less from sediments transported by continental flows. Some traces of marine sediments inside the continental area, in a higher hypsometric quote regarding the actual coastline traces of erosion in some infrastructure works dated of the decade 70' and 80' of 20 th century, are argument of a temporal rise of sea level during the decade 90' of past century.
\end{abstract}

Keywords: Sea level rise, gravel, sediments.

\section{Пєрí $\eta \psi \eta$}

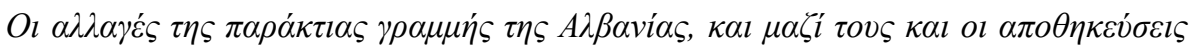

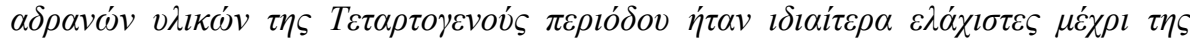

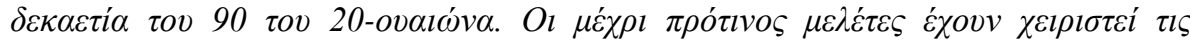

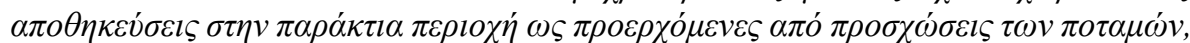

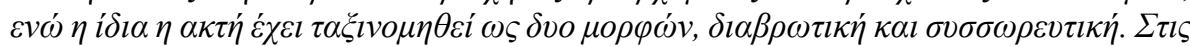

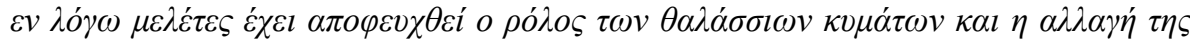

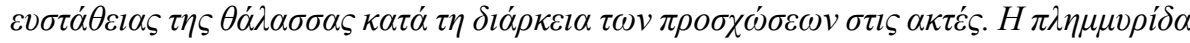

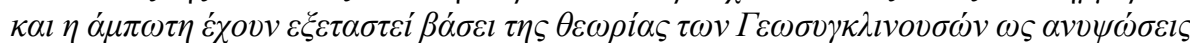

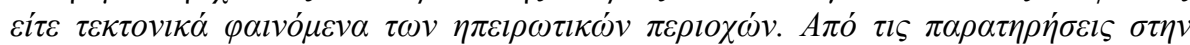

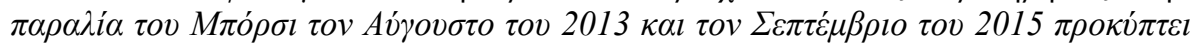

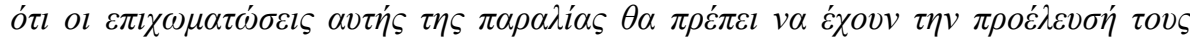

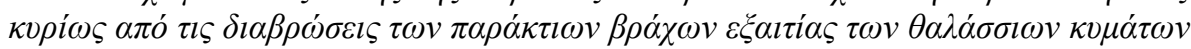

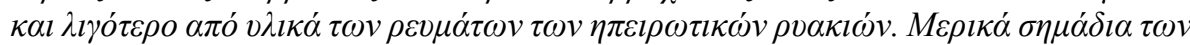

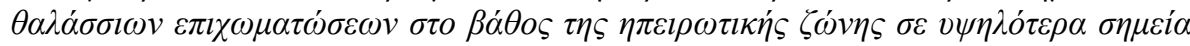

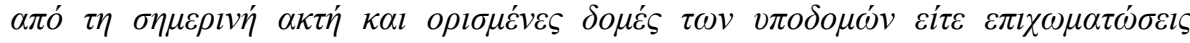

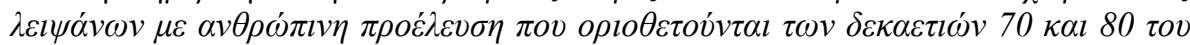

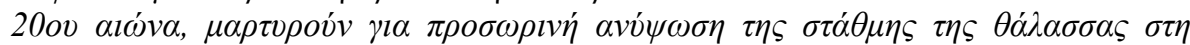

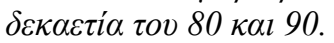

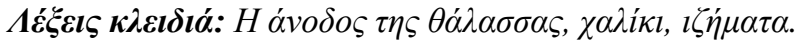




\section{Introduction}

The importance of coast lines cause of high concentration near them of urban areas (Proust et al., 2013), touristic infrastructure and others activities of great economic importance, justify the increasing attention of researches of different scientific fields.

Up to the beginning of $21^{\text {st }}$ century, the attention on the Quaternary deposits in Albania was scarce. This was argued by the absence in important mineral resources of those deposits (Marku, 2014).

In the traditional geological mapping, the quaternary cover, particularly in the area of the contact between those deposits and the older formation, is not designed. Meanwhile by the geological maps of Albania on scale 1:200,000 (Biçoku et al., 1967; Vranai et al., 1997 and Collective, 2012), as marine sediments are treated only the sandy sediments of coastlines.

Albanian geology has suffered by a great discordance with the concepts of European geology, because until the end of $80^{\prime}$ ' decade of $20^{\text {th }}$ century, it has elaborated thesis according to the Theory of Geosynclinals, and although some updates performed some questions still continue to be discussed on the reminiscences of this theory.

The main problem brought by this in the study of quaternary deposits which belong to coastal area, was the neglecting of the eustatic change of the sea level, caused as consequence of global sea level rise or fall, result of climatic changes collected with the combination of glacial-interglacial periods.

Consequently was not considered the impact of the sea transgression and regression processes in the forming of quaternary deposits. This because according to the theory of geosynclinals, the transgression happens only in case of downward movement of geosynclinals; meantime the regression happens where geosynclinals is uplifted. In both cases the global sea level remains constant.

From this point of view, the Albanian lowland, situated adjacent the Adriatic Sea is considered as an alluvial field constructed by river's supply of sediments, which rivers in fact are the second supplier of Adriatic basin with sweet waters after Po River. The deposition of alluvial sediments is considered to be performed in a shallow environment, in continue subsidence, and in contrast with surrounding environment which represents this part of geosynclinals in continue uplift.

As deposits of marine origin are considered only the sands of beach, the lying of which under newer sediments continent ward was considered as trace of sea regression during a time period, where the rivers was in their youthful age characterized by a higher sediment supply. Meantime the erosion phenomena observed in the end of 80' decade, are considered as consequence of sediment supply reduction mainly cause by river ageing (Konomi, 2015).

All the sediment in Ionian coast line, are designated on maps as alluvions. This brings to conclusion that the absence of large lowlands, as in adjacent area of Adriatic coast line, is dedicated to the absence of important rivers in front of Ionian Sea.

So those concepts diminish the role of sea and exaggerate the role of rivers during the process of quaternary deposits forming. In fact worldwide the history of geological science has abandoned geosynclinals concepts more than half century ago, even is concluded that every challenge to update its concept with those of Global Tectonic Theory, as in Albania happen, constitute a useless scientific mistake (Kearey et al., 2009).

Following in this conceptual mistake, caused that in studies of coastal area, or of the lowland adjacent to not be taken into consideration the concepts of transgressive or regressive coasts, or the study of system tracks traces and the role of sea waves. The coast was categorized into two types according to its relief (high or low coast) combined with the erosive and accumulative coastline. So isn't made a categorization of beach based on coast processes. Also neither of studies declares a mean sea level or any base sea level. Every study till now doesn't mention the term "sea level" referring the sea level in the moment of observation. 
Although the tides in Albanian coast line don't exceed the range of 0.5 meters which classify then in the first group of tidal range according to Davies (1964) those show a visible difference in the sea level change as result of Sun influence, which can have impact in coast processes. This change of level, with falling tendency, particularly from June to September (between summer and autumnal equinoxes) remarked in different coastlines (Shëngjin, Durrës, Borsh) during calm state of sea level observations, isn't mentioned in precedent studies.

\section{Geographic position and geological setting of the Borshi Beach}

\subsection{Geographic and historical data}

Borshi Beach is situated in proximity of Ionian coast and is part of this geographical area began to call "Albanian Riviera" after $60^{\text {th }}$ decade of $20^{\text {th }}$ century. Although natural beauty of this beach and others beach of "Riviera" which lay from Llogara Pass, including some villages and the town of Himara, all positioned adjacent of sea and cultural and historical monuments (castles, old churches), until begin of $21^{\text {st }}$ century the touristic potential was unused.

Those areas until the end of $80^{\text {th }}$ decade of $20^{\text {th }}$ century were used only for agricultural and military purposes. The area of hilly relief was covered by artificial terraces to plant trees of lemons and oranges. This activity was abandoned after the year 1991, where the collapse of communist state, the only owner of the land, deepened the economic crisis began from the second half of 70' decade. The crisis was followed by a mass migration of population of this area, mainly toward Greece. The terraced hill degraded, and as consequence the level of erosion began from the first deforestation of hills by natural vegetation four decades ago.

Military installations, besides others, consist in some lines of bunkers, very characteristic for the communist Albania, with the purpose to be a defended position for the infantry and artillery corps. The concreting lines were situated parallel to coastline, beginning from its proximity. The project of bunker's line was fulfilled at 1979 . Their actual condition can help to have an approximate idea regarding the sea level oscillation, and coastline processes that occurred during last four decades.

Borshi beach is situated in Ionian coast line, between Qeparo, Borsh and Piqeras villages. The coast line extends northwest-southeast, forming a triangular shape, which go narrowing until closed adjacent to a cliff structure, in coordinates E 04404455; N 04432230.

The low relief area, where the backshore takes part, is surrounded by mountainous reliefs, which rises immediately, with a steep angle.

Coast line lies about $5 \mathrm{~km}$. It begins to appear immediately after the contact in shape of cliff, between sea and Drisi hill (593m). Here the backshore is followed towards continent by Field of Borshi, in triangle shape to, which northern border is streambed of Borshi torrent, which flow northeastsouthwest. Southward this field narrows until the foothill. After this point the low relief is presented only by backshore.

The beach is intersected by a number of waters torrents, the biggest of which Borshi torrent, and the waters which generate from the spring "Gurra e Borshit". Except those two, all others torrents are seasonal and are dry during the summer. Source of those flows is the water generated from karstik gaps of carbonate rocks which dominate in this region.

The southern extreme of region is Lukova village, where passes the geographic parallel $41^{\circ}$ considered as the most southern extreme where has impact the isostasic rebound which followed the transgression of first Holocene's half.

\subsection{Geological setting of the area}

Refereeing data from the Geological Map of Albania on scale 1:200,000, Albanian Riviera region, where Borshi Beach is included, is part of Çika subzone of Ionian tectonic zone. 
Carbonate rocks belong to lower Jurassic, middle-upper Jurassic, lower Cretaceous and upper Cretaceous. Depositions of Oligocene are composed by sandstone, those of Burdigalian marls and clays and the Aquitanian deposits are of clays. Burdigalian and Aquitanian deposits are partially incohesive.

The above mentioned deposits compose the surrounding area of Quaternary deposits. In the places where the sea is in direct contact with Jurassic, Cretaceous and Paleogene (Oligocene), the backshore is absent, and the coastline is of rock substrate, where the impact of sea waves can be observed through the cliff forms.

Quaternary deposits are represented from sediments of a cohesive coast, mainly gravel of different size and coarse sands.

Here can be observed some tectonics which lies normal to the coastline. Each of those is at the same time a bed of the torrents which flow to the sea, along the beach.

In some places, as Sopoti Hill, are observed some vertical displacements in carbonate rocks, possibly caused from tectonic uplift during Quaternary.

\subsection{Short description of sediments and processes on the coastal area}

The backshore is larger wide of backshore is reached in the northern part of Borshi beach, about 1015 meter, between Drisi and Sopoti hills. Following southward, the backshore remains the only element of the low relief. In the area of Sopoti hill the width of backshore is only 3-4 meter. After this hill the backshore, narrows up to 2 meters in the "Lagja e Mirditoreve", and then shows a tendency to expand until it reach a width of 5-8 meters, and after that closes gradually under the Piqeras village, disappearing in the cliff of Buneci hill. The composition of backshore sediments is white color gravel, originated mainly from the fragmentation and after the modeling of carbonates by the sea waves, and less of sandstones. Sometimes we can detect and some elaborated pieces of glass, plastics, aluminum, that can be considered as sediments of mankind origin.

In the southern expand of the back shore is observed that the gravels of the area adjacent to coastline are followed towards continent by a belt of coarse sand, and this one by another belt of gravel, coarser in size compare with the other one. This last gravel belt ends in a contact with sandy-clay sourronding hills.

The pieces of back gravel are ellipsoidal and rarely spheroids. Their diameter is between 1 and 3-4 cm, but sometimes, their size range up to $10 \mathrm{~cm}$ regarding the longer axe of ellipsoid. Moving seaward backshore is substituted by foreshore and the sizes of foreshore gravel are grower, and in a distance 11.5-2 meters from the coastline appears big piece of rocks in the size of boulders and bigger.

Those big pieces cover a large are till 10-20 meters from the coastline, which coincide with the wave breaking zone. In the northern area of the beach pieces of rock show uniform size $15 \times 10 \times 7 \mathrm{~cm}$, but toward south become grow after a distance 3-4-5 meters from the coastline, reaching a triple respect with those of first belt.

However between the gravels and boulders doesn't exist a well definite border. In the first meters of the foreshore $(3-4 \mathrm{~m})$ boulders are intersected with a thinner gravel compared with that of backshore, and after that the sand replace gradually the gravel between the boulders. This sand show similar visual characteristics with this observed in the backshore of the southern area mentioned above.

After that boulders area and wave breaking zone disappear, seawards, the sea floor is covered only by sand.

\subsection{Areas of wave's transformation and the characteristics of wave's action.}

In general, except during the second half of July and at the beginning of August, the winds are present, and with them and the sea waves caused by air currents. By the observation made, is noted 
than during the months of July, August and September the wave breaking zone began about 20 meters from the coastline.

The dominant wind direction is west-northwest to south-southeast. This determinate the principal direction of wave front movement, which shows small angle of impact with the shoreline, about 1520 degree.

Usually, during the summer days, the waves aren't high, and the swash moves in shoreline only gravels of small sizes, of about $1 \mathrm{~cm}$ and smaller, constructing a small berm on backshore side of coastline, that has a triangular section with dimensions of base and high respectively 10 and $5 \mathrm{~cm}$. While the back swashes drag seawards mostly sand. In the calm days of the summer, can't be observed suspended material in the sea water, and its clearness is high.

During stormy days in summer, by the observations of August 2013 and September 2015, the wave breaking zone begins a little deeper, about 25 meters. Those storms are originated by the same but stronger wind. In such conditions the wave changes obviously the beach landscape.

The shore line advance about 1 meter toward continent, and during the second day of the storm the swashes slams up to 2 meters from this coastline. The potency of wave is such that they can carry pieces of gravel in size of a tennis ball until the ankle of an adult people (about $15 \mathrm{~cm}$ ).

In all cases longshore currents are observed. Their capacity of transportation depends of waves.

In few places, mainly in areas where are some rocks (carbonate) more than 2 meters in size, emerge from the water in the first meters of foreshore, during the storms can be observed some micro ripper currents, which create some holes in the fine gravel of the coastal area.

Usually during the summer the storms ends within three days and the second day is the rougher. During the last day, the storm power begins to fall, and the coast gradually retakes the appearance it had before the storm.

Regarding the winter period, the waves are much rougher, and the coastline moves 2 meters toward continent respecting this of calm days of summer.

Beside the dominant wind, in this can be notified and the wind of "Shirok", which is a characteristic for the whole Albanian coastline, and comes from the south. During the observations, is notified that this wind isn't the cause for any important waving, and as such hasn't any important impact on the coast morphology modeling process.

Based in what we can be able to do from our observation, the coastline, at least during the summer, can be classified as of dissipative type, except some parts where the rocks show the morphology of cliffs, and where the beach can be classified as reflective. This classification was based in the categorization of the beach types from Wright and Short (1984).

\section{Materials and Methods}

This paper is supported in data collected from field observation in Borshi beach during years 2011 (July), 2013 (August) and 2015 (September). Those data are collected in a mode to be compared with similar international research data.

Was a purpose to make a categorization of nearshore, foreshore, backshore, zone, to collect data about the sediment sizes, movement of waves, winds that cause those waves and the wave's power. Also the observation has purpose to create a description of wave activities, distinguishing the waves break zone.

Must be highlighted that, the methods used, can be classified as approximate. But for the Albanian tradition of coastal studies their shown a development with the number of elements studied. 
For dating of the time where events occurred are used historical data, such the year where the operation of bunker's line construction was concluded (year 1979), data carried out from artifacts (date marked on a water fountain 1976), and a relative dating of remains of some plastic products and pharmaceutics, produced from the industry which exist before 1992.

\section{Results}

From the observations was noted than the backshore was composed by gravels which as described in paragraph 2.3 shown an order in size change. Gravels followed by grey coarse sands seawards, in the area of foreshore. Towards continent, where the coast narrows, the gravels are presided by big pieces of stone, in size of boulders and bigger. Those stone sign the maximal distance toward continent, where the sea waves collide during storms.

In the cliffs areas, gravels almost are missing in the subaerial part, but dominates stones in size of boulders and bigger.

This order of sediments leads to the conclusion that the deposits of the coast are of marine nature, formed as result of sea wave activity, which have chopped mainly the carbonate structures situated in the coast of Drisi Hill (593m) and Sopoti Hill $(393 \mathrm{~m})$ and less those of sandstone composition belongs to the hills in the southern part of the sea. The sediment seems to have been transported southward by longshore currents.

Piece of rocks, submerged near the coastline, must be remnant by the erosion of Sopoti Hill. Their disintegration still continues nowadays.

Water flows from continent, the biggest from which is Borshi Torrent, don't appear to have any important impact in the coast. Moreover its mouth isn't much visible and is separated by sea from a gravel barrier in form of berm. This torrent meanders densely in this valley, which speak for its lower energy respect to the sea. The meandering have result more in an erosion caused by the torrent in its valley, which after 1990, was followed by the crash of a bridge.

Ranking of sediments in the southern area, with alternation from coastline towards continent of gravel belt with sand belt and then again gravel until the contact with clay-sand deposition, make to think that the continental gravel belt and the sand belt belongs to another and older coast line, formed by a sea level rise. Its difference with the actual coastline is about $1.5 \mathrm{~m}$.

This idea is reinforced by the observation by founding out to a horizontal sandy layer, $25 \mathrm{~cm}$ thick in the area where the backshore narrows in Sopoti Hill. This layer is situated in the landward side of the street which lies parallel to the coast line. It is covered by clayey-sandy material, inside of which are founded plastic products, produced in Albania, by plant which have stop to be active during the years 1991-92. Once, this street continues until the village Piqeras, south of Borsh. In the area mentioned for the characteristic alternation of sediments in backshore, are encountered tracks of roadbed, which was covered by crude pieces of carbonates. In some places, where the relief is higher and roadbed pulls over from the coast, full trace of roadbed can observed.

Because this road isn't signed in maps, we think that it is an old road of military communication infrastructure. Positioning of bunker just on the landward side of the road, shown that until 1980, this road wasn't vulnerable by sea erosion. A water tap discovered by recent works on still functional part of the road, had stamped on its wall the phrase "viti 1976" (year 1976), which can be considered as the year of road construction. Also we haven't data of request by Albanian Army to Albanian Geological Survey, for intervention on purpose of geological risk avoid during years 1980-90. Must be mentioned that during this time, the bunkers line and military road was considered as "object of special importance", and they had a special status of protection. After 1990, the change of the geopolitical reports, reformed the military doctrine, and the bunker lines and military roads loose the importance and was dismissed by the inventory of armed forces. So remained out of use nobody pays attention to the damage of them. Area wasn't important agricultural point of view, and this area 
was left apart until the step by step population from people migrated from north Albania (mainly from Gojan village) between years 1990-96. Their origin was from a region around $200 \mathrm{~km}$ distant from Borshi, so haven't any knowledge for the situation of region before year 1990.

So, summarizing those factors can be say that a sea level rise between years 1990 and 2000 is possible. In fact between year 1989 and 1995, was observed the phenomena of bunkers plunging in some parts of Adriatic coastline, but this generally, in the prevailed concept of Albanian geology was considered as consequence of sediments supply diminution caused by hydropower dam constructed in some rivers. But this explanation can't justify the bunker plunging in front of Semani river in southern part of Adriatic coastline were in all three important rivers (Shkumbin, Seman, Vjose) the dams are absent. This explanation also isn't valid to justify similar phenomena in the Ionian coastline where the rivers are absent, and the mountainous torrents are predominant.

So, the sea level rise between year 1989 and 1995, followed by its fall may be a more acceptable hypothesis to explain the above described phenomena. With the actual data can't be précised the amplitude of this sea level fluctuation, but can be supposed that its value wasn't less than 1.5 meters.

Must be also underlined that the boulders of the coast line belong to another earlier coastline situated seawards in confront with the actual coastline, but the age of its existence can't be appointed with data of moment.

\section{References}

Biçoku, B., et al., 1967. The geology of Albania. Explanatory text of Geological Map of Albania, Editing House "Naim Frasheri" (In Albanian).

Davies, J.L., 1964. A morphogenic approach to world shorelines, Zeitschrift für Geomorphologie, 8, 27-42. In: Masselink, G. and Short, A.D., eds., (1993), The effect of tidal range on beach morphodynamics and morphology: a conceptual beach model, Journal of Coastal Research, 9(3), 785-800, ISSN 0749-0208.

Konomi, N., 2015. Geo-engineering map of Albania, Albanian Geological Survey (In Albanian).

Kearey, P., Klepeis, K.A. and Vine, F.J., 2009. Global tectonics, 3rd ed. John Wiley \& Sons Ltd, ISBN 978-1-4051-0777-8, Marku, S., 2014. The evolution of the studies on Quaternary in Albania, according to the geological maps on 1:200,000 scale. Microthesis, Faculty of Geology and Mining, Tirana (In Albanian).

MMP, 1974. Guide for navigation in Adriatic and Ionian Sea, First Edition, Ministry of Popular Defense (In Albanian).

Proust, J.N., Tessier, B. and Chaumillon, É., 2013. Coastal sedimentation: State-of-the-art and ongoing research, Géoschiences, 17, 26-35 (In French).

Vranai, A., Shallo, M. and Xhomo, A., 1997. The geology of Albania. Explanatory text of Geological Map of Albania of year 1893, Editing House "Libri Universitar" (In Albanian).

Wright, L.D. and Short, A.D., 1984. Morphodynamic variability of surf zone and beaches: A synthesis, Marine Geology, 56, 93-118. 